\title{
ANALYSING THE EFFORTS OF HAMAS FOR THE PALESTINIAN CAUSE
}

\author{
Dr. Hafiz Hammaduddin \\ Ph.D from Department of International Relations \\ FUUAST \\ Karachi-Pakistan \\ hafizhammaduddin@gmail.com \\ Dr. Naseem Umer \\ Former Teaching Assistant \\ Department of Political Science \\ University of Karachi \\ Karachi-Pakistan \\ naseemumer89@gmail.com \\ Zahid Hussain Dashti \\ Assistant Professor \\ Department of Balochi \\ University of Balochistan \\ Quetta-Pakistan \\ zahiddahti29@gmail.com
}

\begin{abstract}
Here, we examine Hamas' involvement in the Israeli-Palestinian conflict and make recommendations for future action. Public sources and interviews with five contemporary Hamas officials living abroad are used to examine the group's triumphs and failures since its active involvement in the military battle against Israel and Palestinian politics against the other key actor, Fatah, since the beginning of its involvement. Because it was driven into Gaza by the Palestinian Authority and because international players have blocked humanitarian help from reaching Hamas-controlled Gaza, Hamas has fallen short of Palestinians' expectations in terms of military triumph against Israel. Since the people of Gaza have become disgruntled with Hamas' administration due to rising unemployment and the Israeli blockade and attacks, it is expected that Hamas would continue to fight, but that it may largely withdraw from politics because of this.
\end{abstract}




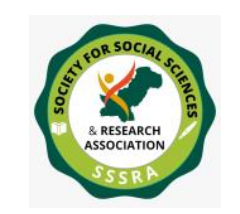

Pak. Journal of Int'L Affairs, Vol 4, Issue 3 (2021)

Analysing the Efforts of Hamas for the ...

Keywords: Palestine, Hamas, Israel, Gaza, Military.

\section{Introduction}

Defining its national identity is challenging for Hamas (also known as the Islamic Resistance Movement), a non-state actor that acts in ways that are similar to those of a state. Since its inception in 1987, the organisation has played an important role in the Israeli-Palestinian conflict, mostly due to its ongoing campaign against Israel. However, the organization's militarization and political activities have had repercussions both inside the community and beyond the world. As a result of the conflict with Fatah, Hamas is now seeking to meet the needs of the Gazan population. Between now and then, Israel's pressure on Palestine has increased as a result of Hamas' violent resistance and extreme political positions. The aggressive image of the organisation also has the potential to erode support and sympathy for the cause of Palestine in general. However, given the fact that Palestine is under Israeli occupation, a non-state armed force such as Hamas will emerge. Hamas is not the first Palestinian armed group to choose to fight for a political solution to the conflict, and if existing circumstances remain unaltered, it will not be the last to do so. Fighting, on the other hand, may not always be the most effective means of achieving a non-state actor's objectives.

Hamas' military and political struggles are examined in this essay, and the author is concerned if the organisation will be able to conduct the fight in accordance with its beliefs. One of the most influential Palestinian groups has a direct influence on the Israeli-Palestinian conflict, as well as the other way around, due to its military, political, social, and diplomatic strategies. Hamas has had a direct impact on the Palestinians' battle for independence since it began its active involvement in the century-old war. In addition, Hamas's transformation during the conflict is strongly linked to the fighting itself. This study's findings, based on Hamas officials' remarks in interviews, show that the group has not fulfilled the political goals it set out to attain at the commencement of its endeavour and that it will most likely only partially return to politics. They appear to have reduced their ambitions and may be able to maintain their cause through fighting.

Hamas' ability to endure the brunt of the battle will be the primary subject of this article. It is not enough to rely on official documents and derived resources, the writers conducted interviews with five senior Palestinian officials who went by the pseudonyms Mahmoud Saeed, Zakariyya Yasin, Muhammed Hamdi, Nasser Mustafa and Yasir Ali, among others. First, a brief history of the Israeli-Palestinian conflict will be presented in the first two sections, after that, we'll look at Hamas' military and political responses to 


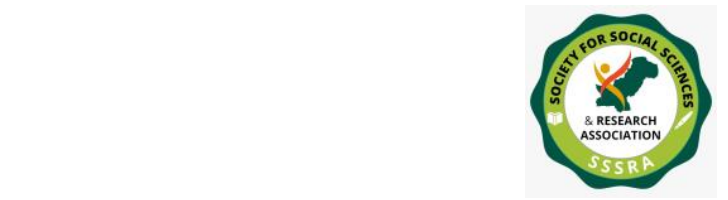

Pak. Journal of Int'L Affairs, Vol 4, Issue 3 (2021)

Analysing the Efforts of Hamas for the ...

the conflict in the next parts. Detailed discussions of Hamas' military and political endeavours will be covered in the following sections.

\section{Nature and Background of Palestine-Israel Conflict}

The first organised and formal efforts to build a Jewish homeland in Palestine began in 1897 with the first World Zionist Congress. The establishment of a Jewish state in Palestine was advocated by Jewish intellectuals and businessmen during this gathering. The World Zionist Organization (WZO) lobbied the Ottoman Sultan to allow the methodical establishment of a permanent Jewish colony in Palestine. Following the obstinate refusal of Sultan Abdulhamid II, they sought support from the British administration for establishing a Jewish homeland in Palestine, which provided them with a proposal known as the 'Uganda Scheme,' which proposed the establishment of a Jewish homeland in the Uasin Gishu region of modern Kenya. It goes without saying that the WZO turned it down. Jewish lobbyists applied pressure to the British government during World War I, and as a result, through the Balfour Declaration, they were able to secure a legal commitment for the establishment of a Jewish state in Palestine in 1917. (Makdisi, 2018) It came as a surprise to Arabs fighting the Ottoman Empire when the British decided in favour of a Jewish homeland because the same territories had been given to them as well as to the Jewish people. From the beginning of the British Mandate until the conclusion, this two-faced approach resulted in conflicts between Palestinians and Jews.

The United Nations organised a committee in 1945 when the British proclaimed that they would no longer be responsible for their commitments in Palestine. The committee ultimately recommended the partition of Palestine into two nations in 1947. The UN General Assembly passed Resolution 181 on November 29, 1947, which divided Palestine. Approximately 56 per cent of the region would be allocated to Jews under the resolution, which is predicated on an increase in Jewish immigration in the future years. (Beinin and Hajjar, 2014) Arabs responded strongly when the decision was made because the Jewish population was just 31 per cent of the general population at the time. Formalized adverbial was defined by Halbrook (1981). Jews announced the foundation of Israel on 14 May 1948. Egypt, Syria, Lebanon, and Iraq declared war on Israel in response to the foundation of a Jewish state on Palestinian land, but Israel was wellprepared, well-equipped, and outnumbered the Arabs in terms of combat capability. Following the fighting that cost the lives of 15,000 Palestinians, Israel held 78 per cent of Palestinian land, while Egypt annexed the Gaza Strip and Jordan annexed the West Bank respectively. (Siniver, 2018) As a result of the division of Palestine by warring countries, including Arab governments, the State of Palestine came into being as a dead state. 


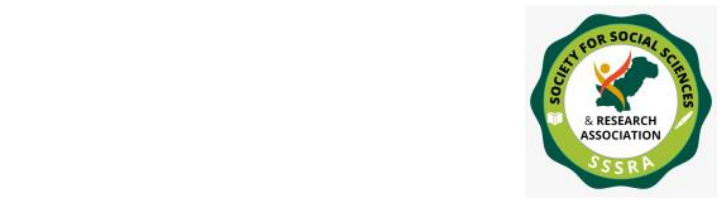

Pak. Journal of Int'L Affairs, Vol 4, Issue 3 (2021)

Analysing the Efforts of Hamas for the ...

Following the War of Independence, the Arab countries and Israel engaged in two further conflicts. When Israel launched a surprise attack on Egyptian air forces during the SixDay War in 1967, it was able to claim victory over the Arabs. Israel gained control of the Golan Heights from Syria, the Sinai Peninsula and the Gaza Strip from Egypt and the West Bank from Jordan during the conflict, among other areas. In the words of Makdisi, "(2010)" Israel's latest occupations were declared unlawful by the United Nations Security Council (UNSC) in Resolution 242. The authors (Beinin and Hajjar, 2010) have stated that When Egypt initiated an attack on Israel on Yom Kippur in October 1973, they wanted to surprise the Israelis. The Egyptians were successful in achieving some early and brief military successes. Nonetheless, Egypt was overcome once more, it is this time, aided by American power as well as Israeli resolve. As a result of the battle, Anwar Sadat withdrew from the Arab-Palestinian cause and agreed to recognise Israel in exchange for Israel returning the Sinai Peninsula to Egypt in accordance with the Camp David Agreement of 1979.

In the 1970s, the Palestinians were in a dire state. Because of the Israeli occupation, the Palestine Liberation Organization (PLO) was forced to relocate to Jordan. Afterwards, it relocated to South Lebanon, where it fought Israeli troops. Some Palestinian armed organisations fled to Tunisia when the Israeli army invaded Lebanon in 1982 and expelled them. The First Intifada, which began in 1987 and claimed the lives of 1,500 Palestinians and 422 Israelis, was started not by terrorists but by regular Palestinians. This first organised civil disobedience operation persisted for several years and helped Palestine reach the top of the world's political agenda and gain popular support. When it comes to (Alin, 1994)

Oslo Agreements were signed in 1993 by Israelis and Palestinians as an attempt at peace, after the First Intifada. Israel agreed to withdraw from Gaza and grant Palestinian selfrule in areas of the West Bank under the terms of the deal. The Palestinians, on the other hand, would acknowledge Israel as a sovereign nation. They did not address the real issues that existed between them. According to Freiden, (2016) " In comparison to the pre-Oslo era, Palestine's position did not improve throughout the disengagement process. There has been no development since the death of Yitzhak Rabin, the Israeli Prime Minister, by an anti-Semitic Jewish fanatic in 1994. Second Intifada began September 28, 2000, when Israeli Prime Minister Ariel Sharon visited the sacred Masjid al-Aqsa and shouted vile comments against the mosque, leading to 3,682 Palestinians and 69 Israelis being killed in the conflict that lasted until 2005. There are several ways to say. (Brym and Araj, 2006). Palestinians' worst revolt in recent memory has led to more ferocious Hamas attacks on Israel and a rise in its popularity among Palestinians as a result. In 2006, Hamas won 60.6 per cent of the vote in the general elections. Israel exploited this 


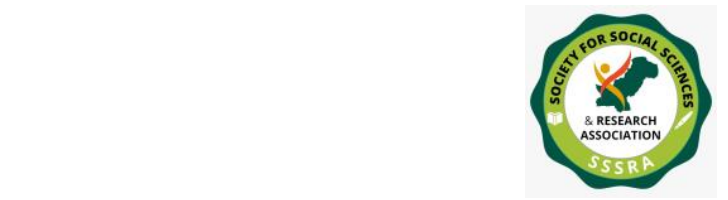

Pak. Journal of Int'L Affairs, Vol 4, Issue 3 (2021)

Analysing the Efforts of Hamas for the ...

unexpected outcome as a reason to blockade Gaza since Hamas refused to accept Israel's requests. According to Levin (2019), The Palestinian Authority (PA) was split into two in 2007 when the Fatah-Hamas war erupted. Ismail Haniyeh was ousted from power by Palestinian President Mahmoud Abbas, who gained control of the Gaza Strip while Fatah retained control of the West Bank. Both sides were killed as a result of the conflict.

From 2006 onwards, as Hamas maintained a virulent anti-Israel attitude, it came into conflict with Israeli soldiers. To combat the danger posed by Hamas, Israel undertook three operations: Operation Cast Lead, Operation Pillar of Defense, and Operation Protective Edge in 2008. It's (Clarke, 2017) In 2011, Palestine applied to join the United Nations (UN) as an independent state, the Security Council refused to approve it because of the predicted U.S. veto. (Broadcasting Corporation of Britain, 2012)

As soon as Donald J. Trump was elected president of the United States in 2016, a new era in the Israeli-Palestinian conflict started, as he publicly supported Israel's government against the Palestinians. the transfer of the US embassy from Tel Aviv to Jerusalem was the first major gesture by the Trump administration showing its unwavering support for Israel (al-Quds). Despite widespread condemnation, he refused to back down. Gazan Palestinians protested the worsening of their living circumstances and the transfer of the US consulate from March 30 to May 15, 2018. There were 183 people murdered and 6,000 injured despite the demonstrators not having guns. The 2019 CFR (CFR) Since Trump's inauguration, Israel's government has annexation of the Jordan Valley, recognised the Golan Heights as Israeli territory, and made Israeli settlements legitimate. As a result, Israel has had the opportunity to legitimate several of its illegal invasions while Trump was president. As if this wasn't bad enough, Trump's son in law and adviser Jared Kushner has crafted a peace proposal that he plans to reveal on January 28, 2020, dubbed the "bargain of the century." The proposal does not call for the establishment of a Palestinian state or the designation of East Jerusalem as the country's capital. An alternative scenario is one in which Israel would oversee a demilitarised Palestine. In addition, Israel will retain control of the Al-Aqsa Mosque and expand its annexation of the West Bank, leaving the Palestinians with no airspace or border control. (The White House, 2020) Although the Palestinians rejected the idea, the Arab States were able to support it without offending the Palestinians in any way. It is expected that (Yeranian, 2020)

\section{Visualising Hamas}

Since its founding in 1987, shortly after the outbreak of the First Intifada, by Ahmed Yassin and Abdel Aziz al-Rantissi, Hamas has served as a non-state entity advocating for 


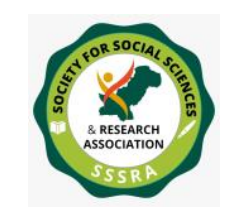

Pak. Journal of Int'L Affairs, Vol 4, Issue 3 (2021)

Analysing the Efforts of Hamas for the ...

Palestinian independence. Since 1948, when Palestinian refugees arrived in Egypt amid members of the Muslim Brotherhood, the group's philosophy and unofficial organisation have been based on that time period. Palestine's Muslim Brotherhood (PMB) was born when Palestine's refugee population returned to the Gaza Strip in 1973 and founded an Islamic Center. (Kodaman \& Sarac, 2006) As a result, the group was already in existence prior to its formal declaration of its existence. They changed their name in 1987 to Hamas under pressure from PMB supporters. Referenced in 2009 by Nimer. 'Post-facto Islamism,' where an existing territorial and ethnic war was Islamized, was an example of 'Islamism from the bottom up' (Hassan al-Banna) and revolutionary 'Islamism from the top down (Sayyid Qutb).' Knudsen noted that Hamas' efforts in reviving Islam in Palestine were driven by the worry that Fatah's theology and practices did not fully support the Palestinian cause in 2005, according to our sources." A more secular culture prevailed in Palestine prior to the rise of the Hamas movement, which saw the number of mosques fall and the practice of veiling in public schools be outlawed. Initially, Hamas built mosques, delivered Islamic courses, and provided humanitarian assistance to Palestinians as a way to promote their religious identity. In 2020, (Karatas, 2020)

The 'Hamas Charter,' which was published in 1988, reveals a great deal about Hamas. The charter explicitly declares that the group's war against Jews would continue "until the adversary is defeated." (Hamas Charter, 1988) According to Article 2, the movement is affiliated with the Muslim Brotherhood (MB). A reference to Izz al-Din al Qassam soldiers, who fought in the 1948 war and fought in the Muslim Brotherhood's jihadi actions from 1968 onward, is made in Article 7. The group's ties to the MB are frequently mentioned in the charter. As stated in Article 12, nationalism is an element of its religious beliefs. Instead of favouring secularism as opposed to sharia (Islamic law) as advocated by Fatah, Hamas regards it as one of the foundations of its ideology. As stated in the work of (Gupta \& Mundra, 2005),

In May 2017, Hamas revised its charter. For Hamas, an independent Palestinian state within pre-war boundaries is acceptable, as stated in the group's newly released "Document of General Principles and Policies." Separating Judaism and Israel indicates that the adversary is not Jews, but Zionists. Third, there is no mention of the MB in the paper. However, not all Hamas adherents are convinced that the group's fundamental aims have changed. He argues that the "Palestinian war with the enemy is everlasting and will continue until Palestine is freed from them." "It's merely an adjustment to the new period," Yasin says (Karatas, 2020)

When Hamas was born in the First Intifada, the Second Intifada solidified its authority and influence from 2000 onward. As a result of Israel's use of disproportionate force and 


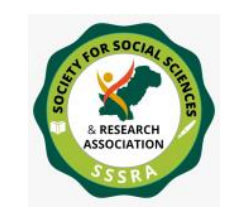

Pak. Journal of Int'L Affairs, Vol 4, Issue 3 (2021)

Analysing the Efforts of Hamas for the ...

the inability of the Fatah-controlled Palestinian Authority to wage a military campaign against Israel in 1996 and 1997, Yassir Arafat was frightened by the increasing popularity of Hamas among the Palestinian people. He authorised Hamas to conduct out military attacks against Israel during the Second Intifada, though. To put pressure on Hamas, Arafat opened the door to confrontation.

While Abbas, Arafat's successor, advocated diplomacy over fighting, Hamas' military victories over Israeli forces won them support among Palestinians. It was elected to rule Palestine in 2006, but after removing Prime Minister Ismail Haniyeh and collaborating with the Middle East Quartet (US, EU, Russia, and Saudi Arabia), Hamas was pushed out of Gaza and West Bank. Following the takeover of the Gaza Strip by Hamas, Fatah was given control of the West Bank. Hamas has consolidated its grip over Gaza's government ever since. Donors from throughout the world, especially Arab countries, have either partially or completely ceased funding Hamas. As of right now, Qatar sends \$15 million a month to Gaza in order to pay the wages of public servants. To know where the money is going, Israel maintains it mediates between the two parties. (AP News, 2019)

Hamas is divided between political and military branches, with no clear distinction between the two. The question of which wing controls the other has been a contentious one. Although the political branch does not get involved in military conflict, Wilson argues that it supports the acts of those engaged in it. "(Wilson, 2015) The military side, on the other hand, is under the direction of Hamas' political wing, according to an official who was questioned. In 2020, (Karatas, 2020) Hamas' legitimacy has split the international world. Several nations, including the United States, Canada, Europe, and Japan (although acknowledging Hamas' election triumph), have classified Hamas a terrorist group because of its willingness to fight against Israel. The Hamas' military arm named the Izz ad-Din al-Qassam Brigades has been registered as a guerrilla faction by New Zealand, Australia, Paraguay and Great Britain. Turkey, China, Russia and Switzerland (as a neutral countries) do not consider it a terrorist organisation. With regards to Arab countries like Saudi Arabia and UAE that have not labelled the group a terrorist organisation despite their disapproval of its policies. (New York Times, 2014) The United Arab Emirates and Saudi Arabia, according to interviewee Saeed, have not formally designated Hamas as a terrorist organisation, but they have detained members of the group on their soil. Furthermore, Egypt barred Hamas leader Ismail Haniyeh from leaving Gaza for a period of three years. In 2020, (Karatas, 2020)

\section{Political \& Financial Outcomes}




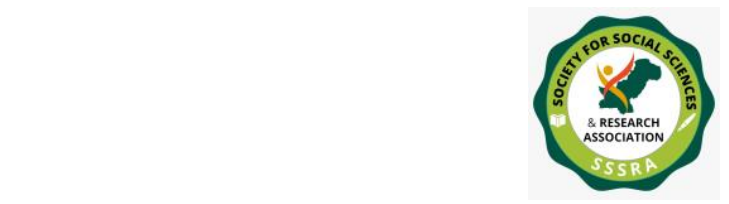

Pak. Journal of Int'L Affairs, Vol 4, Issue 3 (2021)

Analysing the Efforts of Hamas for the ...

Whether Hamas has been successful in its military fight is a matter of debate, but as some interviewed have admitted, Hamas' economic and political future seems bleak. When Hamas won the election in 2006, the Israeli-Palestinian conflict became a huge burden for the organisation. Within a year, Hamas found themselves restricted to the Gaza Strip. There was an abrupt halt in international aid to the Hamas-controlled territory, which resulted in heightened international pressure on the organisation. Israel intensified its offensive against the Gaza Strip and erected a barrier around it. Unemployment soared from 25 per cent to 52 per cent when Hamas assumed control of Gaza, a dramatic change in socioeconomic conditions. As of 2019, (BtSelem, 2019), People in the Gaza Strip are outraged by the fact that the West Bank's unemployment rate is merely 13\%. Public personnel are also affected by the lack of funds. Between 70 and 100 per cent of clerks in the West Bank earn their full wages, whereas clerks in Gaza receive barely 45 per cent. As a result of their economic and social hardships, the residents of Gaza blame the Hamas administration. Media reports and interviews show that while they do not want Hamas to control them, it is their hope that the organisation would continue its violent struggle since they see it as critical to the cause of Palestinians. They want Hamas to dominate them. (The Guardian, 2019) Gaza needs help now more than ever, and despite their historical disagreements, Hamas has authorised Mohammed Dahlan's organisation to operate and deliver supplies in the Gaza Strip. When it comes to the economy, (AlMonitor, 2019) According to interviewer Yasin, Hamas received $\$ 40$ million from Iran in 2019 and would give it to the people of Gaza.

As for the group's international isolation and economic woes, our respondents believe that Hamas would meet even with Saudi Arabia if they were invited. (Karatas, 2020) It has partially reestablished ties with Egypt, it culminated in the reopening of Rafah for trade transport and civilian travel in 2018. The organisation is nevertheless under Egyptian military blockade. As Egypt and Hamas share a common opponent, ISIS, in Sinai, Egypt is willing to collaborate with Hamas. As a result, Egypt is trying to reduce Qatar's influence on Hamas. A two-state solution is also acceptable to the group, something it previously ruled out.

For the first time since 2006, Palestinian President Mahmoud Abbas has suggested that elections would be held shortly. According to our sources, Hamas has no intention of nominating a presidential candidate since the Palestinian people do not want the group to lead them, a truth that the group is well aware of. Instead, it aims to promote a neutral, competent, and dependable one. Both Dahlan and Hamas members will not be nominated. Hamas officials, on the other hand, are cautiously apprehensive about the upcoming polls. Fatah, they say, has been split into four groups, and two of those are already at odds, so there will be greater unrest following the elections. Analysts disagree 


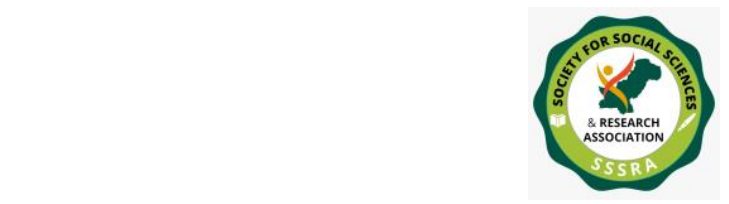

Pak. Journal of Int'L Affairs, Vol 4, Issue 3 (2021)

Analysing the Efforts of Hamas for the ...

with the interviewees in that they feel that Abbas is no longer keen to release a governmental order for conducting elections because he is demanding that Hamas hand over its weapons to the PA, a requirement that the group refuses to accept. (MEM, 2019) However, if elections are held, Hamas seeks 40 per cent participation in the parliament and plans to run for local municipal offices in order to better connect with the populace. In 2020, (Karatas, 2020) Due to Gaza's economic difficulties, Hamas is not projected to hold key administration seats if elections are held. This might be seen as a sign of Hamas' disconnection from the political arena. Economic concerns and diplomatic pressure may have compelled Hamas to retreat from its earlier ambitions to control all of Palestine.

\section{Hamas' Armed Effort}

To liberate Palestinian territory, Hamas is both a military and political organisation. While the political wing controls the Gaza Strip, the military side (the al-Qassam Brigades) fights Israel's soldiers. The precise number of al-Qassam Brigades militants is unknown. In the case of a conflict, Hamas could assemble 20,000 troops, including alQassam Brigades fighters (about 10,000) and security forces and police, according to one research. Bronner $(2008,2008 \mathrm{a})$ According to another estimate, Hamas has between 15,000 and 16,000 militants, including 2,000 highly-trained combatants. There are two ways to look at it: Up to 30,000 operators are also on hand to verify the accuracy of rockets and other weaponry, as well as build tunnels, participate in protests, and organise the populace. As of this writing (Abu-Amer, 2019), Mustafa, an interviewee, claims that there are roughly 40,000 extremists. The year is 2019 (Karatas, 2019)

Because Hamas relies on armed conflict as its primary means of achieving its objectives, it relies on rockets to fight Israel's soldiers because they are cheap to create and operate and because they can be fired without putting operators in danger. Shapir (2009). With little access to advanced parts for its weapons, the Gaza-based militant group Hamas uses reverse engineering to build a wide variety of rockets of varying ranges. As of this writing (Yappin, 2019), A minimal number of people have been killed by rocket assaults as a result. For example, 4,561 missiles were fired from 2001 to 2009, yet only 28 Israelis were killed. While this is true, "rocket strikes help Hamas maintain its political credibility as the major Palestinian resistance movement and enable its leadership to maintain the allegiance of militant members of the organisation who oppose any suspension of attacks." The authors (Byman et al., 2011) In addition, the terror they instil disrupts Israelis' everyday routines and causes psychological suffering. Israel created the Iron Dome missile defence system to protect itself from Hamas' missiles as a precaution. According to the Israeli Defense Force (IDF), the Iron Dome intercepted only 240 of the 690 rockets launched from Gaza in May 2019, killing four people and injuring more than 


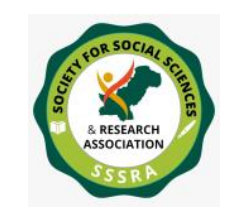

Pak. Journal of Int'L Affairs, Vol 4, Issue 3 (2021)

Analysing the Efforts of Hamas for the ...

200. As of this writing (Kokol, 2019), Thus, the real success rate was substantially lower, raising doubts about the missile defence system's effectiveness. With regard to shortrange missiles that land 3-4 kilometres from their launch point, the system is ineffective. Other Palestinian militant groups, such as the al-Aqsa Martyrs Brigade and Islamic Jihad, also use suicide bombers. Although Palestinian suicide bombs have declined in recent years, the Israeli government built security barriers as a result of more than 300 incidents from 1993 to 2003. According to the future predictions of JVL, There were moreover 700 Palestinian deaths before 2008, with Hamas responsible for almost 400 of these killings. (Zanotti, 2010)

Tunnels are the sole means of escaping the Israeli siege of Gaza, which is enforced by both air and sea. In contrast to Hamas' attacks on Israel, the majority of its tunnels are dug beneath the Gaza-Egypt border. To store weaponry, command stations, and war rooms, Gaza has a network of tunnels. GANOR (Ganor, 2013) According to reports, Hamas spends $\$ 40$ million a year on tunnel construction and upkeep, with 1,500 employees working on the project. (Dostri and Michael) In fact, Israeli troops have been targeted by Hamas attacks using tunnels, which have resulted in the deaths of Israeli soldiers as well as the kidnapping of soldiers. (Barak, 2019) When these tunnels are uncovered, the Egyptian army at the Rafah border or Israel at the Gaza-Israel border demolishes them to prevent weapons smuggling and assaults. During Operation Protective Edge, the IDF uncovered and destroyed 32 tunnels; recently, it has constructed a subterranean barrier composed of galvanised steel to protect itself. The year is 2019 (Akram, 2019). Schanzer claims that Hamas has lost 75 per cent of its budget as a result of the blockade. In 2014, (Solomon) It has been claimed that a lack of weaponry has resulted from the barrier, but Hamas leaders reject this and say they are better prepared for a possible conflict. Even Israeli arms smuggler Hamdi believes that Hamas can get its hands on weapons whenever it needs them. (Karatas, 2020) In 2000, the Israeli police stated that Arab and Israeli arms traffickers had stolen weapons from Israeli army depots and sold them to Fatah rebels, a fact that might substantiate this claim. To put it another way, ISIS terrorists in Sinai accuse Hamas of collaborating with Egypt and Israel in a "traitorous partnership," while Mustafa points out that Bedouin tribes carry weapons across the Egyptian border. (Schweitzer, 2018)

Is there anything Hamas has reaped from this conflict? According to the Israelis, they've effectively immobilised Hamas by enforcing severe rules of engagement. It is expected that (Wilson, 20210) There have been several tunnels demolished, but revenge seldom occurs. When it comes to new ways to attack vs ways to prevent assaults, the two sides disagree. Even though Hamas has been said to be using drone technology to spy on Israeli targets, Israel appears to have taken safeguards against this tactic, as two of its 


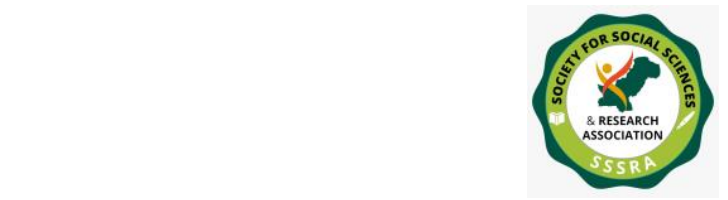

Pak. Journal of Int'L Affairs, Vol 4, Issue 3 (2021)

Analysing the Efforts of Hamas for the ...

drone-makers were supposedly assassinated by Mossad in Tunisian and Malaysia, respectively, according to various media sources (Broadcasting Corporation of Great Britain, 2018) Due to the fact that Hamas is under Israeli and Egyptian blockade, it is unable to quickly acquire weapons or employ hit-and-run tactics, unlike other armed nonstate groups. There is some doubt as to how long smuggled guns can prolong their campaign against Israel. More than 87 per cent of those killed in this violence have been Palestinians, according to UN estimates. It's obvious that this is true. In spite of these facts, Hamas officials continue to retain trust in the group's military capability, according to OCHA (2019). Our respondents indicated that because there are no Jewish settlements in Gaza, Israel is unable to gather intelligence or arrest Palestinians there. They also believe that Hamas has fought against Israel many times before, and each time it has become more powerful. Using reverse engineering, Hamas has been able to learn how to equip drones and build submarines and missiles since 2014. As a result, Hamas is wellprepared for a possible battle. For his part, Saeed praised the effectiveness of the Hamas fighters and asserted that in exchange for the liberation of a single Israeli military service member, Israel released 1,000 Palestinian detainees, 500 of whom had been sentenced to death. Hamas' resistance is seen as the last factor in Israel's decision to leave the Gaza Strip. They are under the impression that the more intense their resistance, further Israel will be forced to withdraw. It is expected to be released in 2020. According to their remarks, Hamas is likely to continue fighting, as several Israeli analysts have predicted as well. (Cohen \& White, 2017, p. 3)

\section{Recommendations}

Since Hamas is a political and democratic resistance movement of the indigenous Palestinian people, the following steps are recommended for productive engagement with Hamas:

Recognition as a democratic representative of Gazans.

Removal from terror and financial blacklists.

Removal of Israeli occupations from Gazan borders.

Negotiations with Hamas to achieve motives of mutual interests.

\section{Conclusion}

Despite Hamas's military successes against Israel, this article concludes that the Palestinian people have been let down by Hamas because the Palestinian Authority has relegated them to the Gaza Strip, and foreign players have stopped aid from accessing the region controlled by Hamas. This means Hamas was unable to achieve its goals. Due to its belief in the futility of non-violent resistance, Hamas will likely continue its campaign 
against Israel. That choice to govern through democratic elections has resulted in a blockade, unemployment, and widespread unhappiness among the Palestinian people. The same people, though, urge the gang to continue its battle. Also aware, Hamas aims to step back from politics, but not altogether. In the course of time, it has softened its stance on a two-state solution. Hamas' actions and metamorphosis, on the other hand, have no bearing on where the Palestinian struggle will go next. Fresh inter-and intra-factional fights are not ruled out, notwithstanding the group's reluctance to take on the role of government. 


\section{References}

AAA, (2019) "Hamas Uses Parcels as New Weapon of War," Asharq Al-Awsat, (July 29, 2019), retrieved from https://aawsat.com/english/home/article/1834391/hamasuses-parcels-new-weapon-war.

Abu-Amer, A. (2019). "Hamas' Weapons Are the Focus of Israel and the Region's Targets," Middle East Monitor, (April 3, 2019), retrieved from https://www.middleeastmonitor.com/20190403-hamas-weapons-are-the-focus-ofisrael-and-the-regions-targets/; Michael and Dostri, "The Hamas Military Buildup."

Akram, F. (2019). "Hamas Has Developed a Vast Arsenal in Blockaded Gaza, AP News, (March 25, 2019), retrieved from https://apnews.com/9977b51fc0754009b932c860daef579e.

Alin, E.G. (1994). "Dynamics of the Palestinian Uprising: An Assessment of Causes, Character, and Consequencese," Comparative Politics, Vol. 26, No. 4 (1994), pp. 479-498, DOI:10.2307/422027.

Al-Monitor. (2019). "Hamas Promotes Relief Work of Abbas' Fatah Rival," Al-Monitor, (February 12, 2019), from https://www.almonitor.com/pulse/originals/2019/01/gaza-hamas-dahlan-aid-relief-work-

pressure.html. Moreover, Dahlan is unwanted by supporters of Hamas, e.g. Turkey. When Yahya Sinwar, one of the top Hamas military leaders, met Dahlan in Cairo in 2017, Turkey refused to meet Hamas leaders other than their president. See, "Sinwar and Dahlan's Cairo Face-To-Face," Al-Monitor, (June 14, 2017), from https://www.al-monitor.com/pulse/originals/2017/06/israel-mohammeddahlan-cairo-hamas-gaza-yahya-sinwar.html.

AP News. (2019). "Official: Israel to Allow Qatari Payment to Hamas," AP News, (January 24, 2019), from https://apnews.com/c005e9b369894be1b2564334ad89b46e

Barak, M. (2019). The "Tunnel Strategy" Among Palestinian Armed Factions in the Gaza Strip, (Herzliya: IDC, 2019), p. 3.

BBC. (2012)."Q\&A: Palestinians' Upgraded UN Status," BBC, (November 30, 2012), from https://www.bbc.com/news/world-middle-east-13701636. 
BBC. (2018). "Palestinian Lecturer and Hamas Member Killed in Malaysia," BBC, (April 21, 2018), retrieved from https://www.bbc.com/news/world-asia43851065.

Beinin, J. and Hajjar, L. (2010). Palestine, Israel and the Arab-Israeli Conflict, p. 6. Kelman calls the new status the 'Palestinianization' of the Arab-Israeli conflict, leaving the conflict to Palestinians as other Arab states have avoided countering Israel from the time of the Yom Kippur War onward. See, Kelman, "The IsraeliPalestinian Peace Process and Its Vicissitudes," p. 289.

Beinin, J. and Hajjar, L. (2014). Palestine, Israel and the Arab-Israeli Conflict, (Tacoma, WA: MERIP, 2014), p. 4.

Bronner, E. (2008). "Hamas in Largest Arms Buildup Yet, Israeli Study Says," The New York Times, (April 10, 2008), retrieved from https://www.nytimes.com/2008/04/10/world/middleeast/10mideast.html.

Brym, R.J. and Araj, B. (2006). "Suicide Bombing as Strategy and Interaction: The Case of the Second Intifda," Social Forces, Vol. 84, No. 4 (2006), pp. 1969-1986.

BtSelem. (2019). "Forced Unemployment: Palestinian Residents of Gaza Who Worked in Israel Until 2000 Describe How Their Lives Came Crashing Down Because of the Unemployment Forced Upon Them," BtSelem, (June 6, 2019), retrieved from https://www.btselem.org/gaza_strip/20190606_forced_unemployment.

Byman, D. and Goldstein, G. (2011). The Challenge of Gaza: Policy Options and Broader Implications, (Washington: Brookings, 2011), p. 5.

CFR. (2019). "Global Conflict Tracker," CFR, (December 3, 2019), from https://www.cfr.org/interactive/global-conflict-tracker/conflict/israeli-palestinianconflict.

Clarke, C.P. (2017). "Hamas's Strategic Rebranding," The Rand Blog, (May 17, 2017), from https://www.rand.org/blog/2017/05/hamas-strategic-rebranding.html.

Cohen and White. (2017). Hamas in Combat, p. ix.

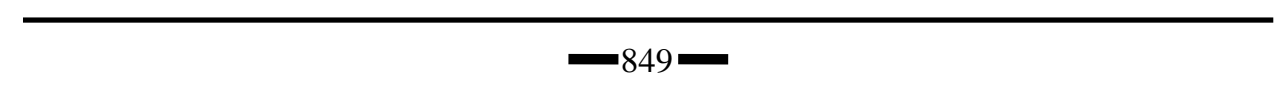


Cohen, Y. and White, J. (2019). Hamas in Combat: The Military Performance of the Palestinian Islamic Resistance Movement, (Washington: Washington Institute, 2019), p. 8;

Frieden, J.A. (2016). "The Root Causes of Enduring Conflict: Can Israel and Palestine Co-exist?," in John Ehrenberg and Yoav Peled (eds.), From Israel and Palestine: Alternative Perspectives on Statehood, (New York: Rowman and Littlefield, 2016), pp. 63-75.

Ganor, B. (2013). "Israel and Hamas," Orbis, Vol. 57, No. 1 (2013), pp. 120-134.

Goldenberg, S. (2000). "Guns For Sale--How Stolen Israeli Weapons Arm Fatah's Fighters," The Guardian, (December 16, 2000), retrieved from https://www.theguardian.com/world/2000/dec/16/israel.

Gupta D.K. and Mundra, K. (2005). "Suicide Bombing as a Strategic Weapon: An Empirical Investigation of Hamas and Islamic Jihad", Terrorism and Political Violence, Vol. 17, No. 4 (2005), pp. 573-598.

Halbrook, S. (1981) "The Alienation of a Homeland: How Palestine Became Israel," The Journal of Libertarian Studies, Vol. 5, No. 4 (1981), pp. 357-374.

Hamas Charter. (1988). "Hamas Covenant", Hamas Charter, (August 18, 1988), from http://www.hamascharter.com/assets/hamas-covenant-1988-source.pdf.

JVL. (2020). "Fact Sheets: Israel's Security Fence," Jewish Virtual Library, retrieved from https://www.jewishvirtuallibrary.org/israel-rsquo-s-security-fence.

Karatas, I. (2019). Interview with Nasser Mustafa by Ibrahim Karatas, (January 5, 2019).

Karatas, I. (2020). Interview with Mahmoud Saeed by Ibrahim Karatas, (January 5, 2020).

Karatas, I. (2020). Interview with Muhammed Hamdi by Ibrahim Karatas, (January 5, 2020).

Karatas, I. (2020). Interview with Zakariyya Yasin by Ibrahim Karatas, (January 5, 2020). 
Knudsen, A. (2005). "Crescent and Sword: The Hamas Enigma," Third World Quarterly, Vol. 26, No. 8 (2005), pp. 1373-1388.

Kodaman, T. \& Sarac, E. (2006). "Hamas (Hareket-Ul Mukavemet-Ul Islamiye-Islami Direnis Hareketi)," Akademik Orta Dogu, Vol. 1, No. 1 (2006), pp. 177-197.

Kokol, S. (2019). "700 Rockets, 240 Intercepts, 4 Dead Israelis: Is the Iron Dome Getting Worse?" JTA, (May 7, 2019), retrieved from https://www.jta.org/2019/05/07/israel/700-rockets-240-intercepts-4-dead-israelisis-the-iron-dome-getting-worse.

Lappin, Y. (2019). Particularly, the anti-Hamas/pro-Israeli stance of Egypt after the military coup in 2013 has led to the destruction of many tunnels that had been used for smuggling parts and standard rockets. See, Yaakov Lappin, "Report Sheds Light on Hamas's Sinai Arms Smuggling," The Investigative Project, (January 17, 2019), retrieved from https://www.investigativeproject.org/7785/report-sheds-light-on-hamas-sinaiarms-smuggling.

Levin, D. (2019). "Iran, Hamas and Palestinian Islamic Jihad," The Iran Primer, (July 9, 2018), from https://iranprimer.usip.org/blog/2018/jul/09/iran-hamas-andpalestinian-islamic-jihad.

Makdisi, K. (2018). Palestine and the Arab-Israeli Conflict: 100 Years of Regional Relevance and International Failure, (Barcelona: Menara, 2018), p. 5.

Makdisi. (2010). Palestine and the Arab-Israeli Conflict, p. 6.

MEM. (2019). "Will Palestinians Actually Hold Legislative and Presidential Elections?" Middle East Monitor, (December 4, 2019), from https://www.middleeastmonitor.com/20191204-will-palestinians-actually-holdlegislative-and-presidential-elections/.

Michael and Dostri, "The Hamas Military Buildup," p. 52.

Nimer, M. (2009). "Charting the Hamas Charter Changes," Insight Turkey, Vol. 11, No. 4 (2009), pp. 115-130.

NYT. (2014). "Arab Leaders, Viewing Hamas as Worse than Israel, Stay Silent," The New York Times, (July 31, 2014), from 
https://www.nytimes.com/2014/07/31/world/middleeast/fighting-political-islamarab-states-find-themselves-allied-with-israel.html.

OCHA. (2019). "Data on Casualties," OCHA, retrieved from http://www.ochaopt.org/data/casualties.

Schweitzer, Y. (2018). "Salafi Jihadism in Gaza as Opposition to Hamas Rule," in Kurz, Dekel, and Berti (eds.), The Crisis of the Gaza Strip, pp. 61-66.

Shapir, Y.S. (2009). "Hamas' Weapons," Strategic Assessment, Vol. 11, No. 4 (2009), pp. 51-57.

Siniver, A. (2018). "Arab-Israeli Conflict," The Encyclopedia of Diplomacy, (February 27, 2018), from https://onlinelibrary.wiley.com/doi/full/10.1002/9781118885154.dipl0337.

Solomon, A.B. (2014). "Egypt's Sisi Is Set to Take Crackdown on Muslim Brotherhood to Hamas in Gaza," The Jerusalem Post, (January 15, 2014), retrieved from https://www.jpost.com/Middle-East/Egypts-Sisi-understands-Hamas-is-linked-toMuslim-Brotherhood-he-struggles-with-athome-338229.

The Guardian. (2019). "Hamas Violently Suppresses Gaza Economic Protests," The Guardian, (March 21, 2019), retrieved from https://www.theguardian.com/world/2019/mar/21/hamas-violently-suppressesgaza-economic-israeli-border-protests; "Hamas Denies Forming New Government in Gaza," Middle East Monitor, (April 20, 2019), retrieved from https://www.middleeastmonitor.com/20190420-hamas-denies-forming-newgovernment-in-gaza/; David Pollock, "Gaza Public Rejects Hamas, Wants Ceasefire," The Washington Institute, (January 15, 2014), retrieved from https://www.washingtoninstitute.org/policy-analysis/view/gaza-public-rejectshamas-wants-ceasefire; "88 Percent of Palestinians Believe Armed Struggle Is the Best Way to Achieve Independence," Times of Israel, (December 16, 2012), retrieved from https://www.timesofisrael.com/hamas-political-strategy-trumpsthat-of-fatah-new-poll-finds/.

The White House. (2020) "Peace to Prosperity," The White House, (January, 2020), from https://www.whitehouse.gov/peacetoprosperity/.

Wilson, T. (2015). Hamas Today: An Assessment of Alliances and Capabilities, (London: Centre for the New Middle East, 2015), p. 2. 
Wilson. (2020). Hamas Today, p. 8.

Yeranian, E. (2020). "Arab States Pledge Palestinian Support, Take No Action Against Trump Peace Plan," Voa News, (February 1, 2020), from https://www.voanews.com/middle-east/arab-states-pledge-palestinian-supporttake-no-action-against-trump-peace-plan.

Zanotti, J. (2010). Hamas: Background and Issues for Congress, (Washington, D.C.: Congressional Research Service, 2010), p. 4. 